\title{
Preliminary evaluation of the effectiveness of visible implant elastomer and coded wire tags for tagging young-of-the-year Atlantic sturgeon, Acipenser oxyrinchus
}

\author{
Andrzej Kapusta, Arkadiusz Duda, Grzegorz Wiszniewski, Ryszard Kolman
}

Received - 30 September 2015/Accepted - 04 December 2015. Published online: 31 December 2015; OInland Fisheries Institute in Olsztyn, Poland Citation: Kapusta A., Duda A., Wiszniewski G., Kolman R. 2015 - Preliminary evaluation of the effectiveness of visible implant elastomer and coded wire tags for tagging young-of-the-year Atlantic sturgeon, Acipenser oxyrinchus - Arch. Pol. Fish. 23: 227-230.

\begin{abstract}
The aim of the study was to determine the retention rates of visible implant elastomer (VIE) and coded wire tags (CWT) and the impact tagging had on the growth of Atlantic sturgeon, Acipenser oxyrinchus Mitchill, during an eight-week rearing period under laboratory conditions. Two size groups of young-of-the-year (YOY) sturgeon were used in the study. The tagging was not found to have a significant impact on the final total length or body weight or the condition coefficient of the sturgeon from either size group. Sturgeon survival in the different groups ranged from 90.6 to $100 \%$. Mortality was not noted until two (CWT) and four (VIE) weeks following tagging and was probably not linked to tagging. The retention rate for VIE tags implanted in the rostrum in both size groups was $100 \%$, while for tags implanted at the base of the pectoral fin was $93.5 \%$. The retention of CWT in the smaller fish was $90 \%$, and in the larger sturgeon it was $100 \%$. Tagging small sturgeon with CWT and VIE is minimally invasive, and it did not impact the growth or condition of the tagged fish.
\end{abstract}

Keywords: fish, hatchery experiment, marking, retention rates, tagging

\footnotetext{
A. Kapusta [ $\equiv]$, A. Duda, G. Wiszniewski, R. Kolman

Department of Ichthyology

Inland Fisheries Institute in Olsztyn

Oczapowskiego 10, 10-719 Olsztyn, Poland

e-mail: a.kapusta@infish.com.pl

Present address:

Department of Hydrobiology

Inland Fisheries Institute in Olsztyn
}

Restocking programs are implemented widely to rebuild stocks of fish species that are threatened with extinction (Molony et al. 2003, Bell et al. 2008). Tagging fish with a variety of tags is standard practice in freshwater fisheries studies (Lucas and Baras 2000). Individual tagging of fish is often used to determine growth and migration patterns and to estimate population parameters such as survival or size (Pine et al. 2003, Zale et al. 2012). Selecting the appropriate tagging or marking method is of particular importance when evaluating the effectiveness of restocking when using fish reared in hatcheries (Hamel et al. 2012).

Visible implant elastomer (VIE; Northwest Marine Technology, USA) tags are used widely to mark groups of fish in tagging and mark-recapture studies using various combinations of colors and tagging locations on the fish (Brennan et al. 2007, Bolland et al. 2009). VIE tags are used most frequently to tag fish in short-term experiments. Similarly to salmonids (Skalski et al. 2009), VIE tags can be used advantageously with sturgeon as the first tagging method in fish that are too small to mark with tags that can be read in long-term studies. Similarly to VIE, coded-wire tags (CWT; Northwest Marine Technology, USA) can be used quickly and easily with small fish; however, these do differ significantly with

\footnotetext{
(c) Copyright by Stanisław Sakowicz Inland Fisheries Institute in Olsztyn.

(c) 2015 Author(s). This is an open access article licensed under the Creative Commons Attribution-NonCommercial-NoDerivs License (http://creativecommons.org/licenses/by-nc-nd/3.0/).
} 
substantially higher retention rates over the long term (Brennan et al. 2007, Simon and Dörner 2011).

In light of their long life spans and the sizes they reach, tagging sturgeon is demanding. The smallest sturgeon are tagged using methods that allow identifying groups, while in larger specimens tags that allow identifying individuals can be used. The retention time of chemical marks used in small sturgeon is relatively short and requires having specialist equipment to read the marks (Lochet et al. 2009). CWT or VIE tags could possibly be an alternative to chemical marks for short-term tagging small sturgeon. The aim of this study was to determine the retention times of tags and the impact of tagging on growth during an eight-week period of rearing under laboratory conditions.

The study material was sturgeon obtained through rearing in recirculating systems (RAS; Szczepkowski et al. 2011, Piotrowska et al. 2013). Two size groups were used in the study: smaller specimens (group S: mean total length, $\mathrm{TL}=125 \mathrm{~mm}$ and mean body weight, $\mathrm{BW}=6.6 \mathrm{~g}$, age 5 months) and larger specimens (group L: mean total length, TL=220 $\mathrm{mm}$ and mean body weight, $\mathrm{BW}=38.7 \mathrm{~g}$, age 5 months). During the eight-week trial the sturgeon were held in six rearing tanks with volumes of $0.27 \mathrm{~m}^{3}$ each. Water temperature during the trial was maintained at $21.0 \pm 0.5^{\circ} \mathrm{C}$. Water oxygen saturation at the tank outflows did not drop below $60 \%$, and water $\mathrm{pH}$ fluctuated within a range of 7.5-7.6. The fish were fed Nutra HP feed (Skretting, France). The daily feed ratio was $5 \%$ of the stock biomass for the fish in group $\mathrm{S}$ and $3 \%$ for the fish in group L.

Each of the sturgeon size groups was divided into three parts comprising fish tagged with CWT (1), VIE (2), and the control (3). Before tagging and during measurements, the sturgeon were anesthetized with an etomidate solution applied to the gills with a syringe $\left(5.0 \mathrm{ml} \mathrm{dm}^{-3}\right.$, IRS Olsztyn, Poland). Stainless steel, magnetized CWT tags (1.6 mm in length and $0.25 \mathrm{~mm}$ in diameter) were injected manually with a Mark IV injector. Single tags were located at the bottom of the rostrum. Fluorescent yellow VIE tags about $2 \mathrm{~mm}$ in length were placed at the same location. A second VIE tag of the same color and length was placed at the base of the left pectoral fin. The VIE tags were administered using a manual injector equipped with a $0.3 \mathrm{ml}$ syringe with a $12 \mathrm{~mm}$ long needle. Fish size was monitored on the day of the trial and then at two week intervals. Body weight (BW \pm $0.1 \mathrm{~g}$ ), total body length (TL $\pm 1 \mathrm{~mm}$ ), and fork length (FL $\pm 1 \mathrm{~mm}$ ) were measured and the fish condition coefficient (CF) and survival (S) were calculated.

All of the statistical analyses were performed with Statistica (StatSoft). Statistical analysis was preceded by data transformation $(\log (x+1))$. Homogeneity of

Table 1

Initial and final length and body weight and condition coefficient and survival in two size groups of $A$. oxyrinchus tagged with visible implant elastomer tags (VIE) and coded wire tags (CWT). Data represent means \pm standard deviation. Mean values in the same size group and in the same row with different letter indexes differ significantly statistically (Tukey's post hoc test $\mathrm{P}<0.05$ )

\begin{tabular}{|c|c|c|c|c|c|c|}
\hline \multirow[b]{2}{*}{ Parameters } & \multicolumn{3}{|l|}{ Group S } & \multicolumn{3}{|l|}{ Group L } \\
\hline & Control & VIE & CWT & Control & VIE & CWT \\
\hline Initial total length (mm) & $120 \pm 1.7$ & $134 \pm 14.3$ & $123 \pm 13.3$ & $258 \pm 35.5$ & $232 \pm 23.2$ & $213 \pm 20.9$ \\
\hline Final total length (mm) & $175 \pm 39.7$ & $201 \pm 37.8$ & $188 \pm 40.0$ & $300 \pm 22.3$ & $298 \pm 38.9$ & $301 \pm 28.2$ \\
\hline Initial fork length (mm) & $89.4 \pm 11.0$ & $103 \pm 11.0$ & $93.5 \pm 10.0$ & $163 \pm 13.1$ & $176 \pm 18.0$ & $164 \pm 16.7$ \\
\hline Final fork length (mm) & $132^{\mathrm{a}} \pm 29.7$ & $154^{\mathrm{b}} \pm 29.7$ & $144^{\mathrm{ab}} \pm 31.7$ & $227 \pm 19.1$ & $231 \pm 28.5$ & $230 \pm 21.6$ \\
\hline Initial body weight (g) & $6.6 \pm 2.18$ & $9.1 \pm 2.63$ & $7.3 \pm 2.21$ & $34.7 \pm 8.85$ & $46.1 \pm 13.60$ & $35.0 \pm 9.97$ \\
\hline Final body weight (g) & $21.2 \pm 14.44$ & $28.2 \pm 16.90$ & $24.3 \pm 16.05$ & $90.5 \pm 19.31$ & $90.8 \pm 33.90$ & $91.3 \pm 27.09$ \\
\hline Initial condition factor & $0.38 \pm 0.05$ & $0.38 \pm 0.03$ & $0.39 \pm 0.03$ & $0.35 \pm 0.02$ & $0.36 \pm 0.04$ & $0.35 \pm 0.03$ \\
\hline Final condition factor & $0.35 \pm 0.03$ & $0.32 \pm 0.01$ & $0.32 \pm 0.05$ & $0.33 \pm 0.03$ & $0.33 \pm 0.10$ & $0.32 \pm 0.03$ \\
\hline Survival (\%) & 100 & 100 & 100 & 100 & 96.9 & 90.6 \\
\hline
\end{tabular}


Table 2

Results of initial tag retention trials for visible implant elastomer tags (VIE) and coded wire tags (CWT) in two size groups of $A$. oxyrinchus

\begin{tabular}{|c|c|c|c|c|c|c|c|}
\hline \multirow[b]{2}{*}{ Fish group } & \multirow[b]{2}{*}{ Tag type } & \multirow[b]{2}{*}{ Implant location } & \multirow{2}{*}{$\begin{array}{l}\text { Number } \\
\text { tagged }\end{array}$} & \multicolumn{4}{|c|}{ Tag retention (weeks after tagging) } \\
\hline & & & & 2 & 4 & 6 & 8 \\
\hline \multirow{2}{*}{ Group S } & VIE & Snout & 30 & 100 & 100 & 100 & 100 \\
\hline & CWT & Snout & 30 & 93.3 & 93.3 & 90 & 90 \\
\hline \multirow[t]{3}{*}{ Group S } & VIE & Snout & 32 & 100 & 100 & 100 & 100 \\
\hline & & Base of pectoral fin & 32 & 100 & 96.9 & 93.5 & 93.5 \\
\hline & CWT & Snout & 32 & 100 & 100 & 100 & 100 \\
\hline
\end{tabular}

variance was verified with Levene's test. The impact of tagging on sturgeon length and weight growth and condition during the trial was determined with two-way analysis of variance (ANOVA). After confirming statistically significant differences $(\mathrm{P} \leq 0.05)$, Tukey's test was applied for unequal groups.

Tagging was not found to have a significant impact on the final sturgeon total body length or body weight or condition coefficient in either of the size groups ( $\mathrm{P}>0.05$; Table 1). Sturgeon survival in the different groups ranged from 90.6 to $100 \%$. Mortality was not noted until two (CWT) and four (VIE) weeks following tagging, so it was probably not linked with sturgeon tagging. The retention of VIE tags implanted in the rostrum in both size groups was $100 \%$, while that at the base of the pectoral fin was $93.5 \%$ (Table 2). Some of the smallest sturgeon lost their CWT in the first six weeks of the trial. CWT tag retention at the end of the trial was $90 \%$ in group S, while none of the sturgeon from group L lost their CWT (100\% retention).

The short-term CWT retention rates achieved in the current study were high. Usually, CWT retention rates range from 90 to $100 \%$ (Isely and Fontenot 2000, Brennan et al. 2007, Simon and Dörner 2011, Zakęś et al. 2015), but in some instances the loss of these tags can be as high as almost $80 \%$ (Pitman and Isaac 1995, Guy et al. 1996). Similarly, the retention of VIE tags in the short term is high, but the implant location of the tag significantly affects it retention (Brennan et al. 2007, Bolland et al. 2009). The results of the current trial also indicate that the implant location has a substantial impact on VIE tag retention.

Tagging and recapture is a method used to evaluate the effectiveness of restocking sturgeon using material from hatcheries. The effectiveness of sturgeon restocking is evaluated based on tagging with various types of tags (St. Pierre 1999, Jatteau et al. 2011), including CWT (Mohler et al. 2012, Wu et al. 2014). Short-term evaluations of restocking can be conducted using VIE tags that are easier to read. The results of this study indicate that the retention time of VIE tags depends on the implant location.

To summarize, tagging small sturgeon with CWT and VIE tags is minimally invasive, and it does not impact the growth or condition of the tagged fish. CWT and VIE tags can be injected into various sites on the sturgeon. In future, it should be determined how effective it is to inject CWT and VIE tags in several different body sites in young sturgeon. In the case of VIE, presumably thanks to this the detection period of these tags would be longer. In turn, injecting several CWT, for example in the pectoral fin, could permit in vivo detection by clipping off the section of fin containing the tag.

Acknowledgements. This work was supported by statutory research project no. S-025 at the Inland Fisheries Institute, Olsztyn.

Author contributions. A.K. conceived of and designed the experiments, A.D. and G.W. implemented the experiments and analyzed the data, R.K. designed and supervised the experiment, A.K. wrote the paper. 


\section{References}

Bell J.D., Leber K.M., Blankenship H.L., Loneragan N.R., Masuda R. 2008 - A new era for restocking, stock enhancement and sea ranching of coastal fisheries resources - Rev. Fish. Sci. 16: 1-9.

Bolland J.D., Cowx I.G., Lucas M.C. 2009 - Evaluation of VIE and PIT tagging methods for juvenile cyprinid fishes - J. Appl. Ichthyol. 25: 381-386.

Brennan N.P., Leber K.M., Blackburn B.R. 2007 - Use of coded-wire and visible implant elastomer tags for marine stock enhancement with juvenile red snapper Lutjanus campechanus - Fish. Res. 83: 90-97.

Guy C.S., Schultz R.D., Clouse C.P. 1996 - Coded wire tag loss from paddlefish: a function of study location - North Am. J. Fish. Manage. 16: 931-934.

Hamel M.J., Hammen J.J., Pegg M.A. 2012 - Tag retention of T-bar anchor tags and passive integrated transponder tags in Shovelnose sturgeon - North Am. J. Fish. Manage. 32: 533-538.

Isely J.J., Fontenot Q.C. 2000 - Retention of coded wire tags in juvenile shortnose sturgeon - North Am. J. Fish. Manage. 20: 1040-1043.

Jatteau P., Castelnaud G., Rochard E., Gessner J., Lepage M. 2011 - Tagging European and Atlantic sturgeons in Europe - In: Biology and conservation of the Atlantic European sturgeon Acipenser sturio L., 1758 (Eds) P. Williot, E. Rochard, N. Desse-Berset, F. Kirschbaum, J. Gessner, Springer-Verlag Berlin Heidelberg: 349-355.

Lochet A., Jatteau P., Gessner J. 2011 - Detection of chemical marks for stocking purposes in sturgeon species - J. Appl. Ichthyol. 27: 444-449.

Lucas M.C., Baras E. 2001 - Migration of freshwater fishes Blackwell Science, Oxford.

Mohler J.W., Sweka J.A., Kahnle A., Hattala K., Higgs A., DuFou, M., Breece M.W., Fox D.A. 2012 - Growth and survival of hatchery-produced Atlantic Sturgeon released as young-of-year into the Hudson River, New York - J. Fish Wildl. Manag. 3: 23-32.
Molony B.W., Lenanton R., Jackson G., Norriss J. 2003 Stock enhancement as a fisheries management tool Rev. Fish Biol. Fish. 13: 409-432.

Pine W.E., Pollock K.H., Hightower J.E., Kwak T.J., Rice J.A. 2003 - A review of tagging methods for estimating fish population size and components of mortality - Fisheries, 28: 10-23.

Piotrowska I., Szczepkowska B., Kozłowski M., Wunderlich K., Szczepkowski M. 2013 - Results of the larviculture of Atlantic sturgeon (Acipenser oxyrinchus) fed different types of diets - Arch. Pol. Fish. 21: 53-61.

Pitman V.M., Isaac JR J. 1995 - Coded wire tag retention by paddlefish at three implant sites - North Am. J. Fish. Manage. 15: 878-880.

Simon J., Dörner H. 2011 - Growth, mortality and tag retention of small Anguilla anguilla marked with visible implant elastomer tags and coded wire tags under laboratory conditions - J. Appl. Ichthyol. 27: 94-99.

Skalski J.R., Buchanan R.A., Griswold J. 2009 - Review of marking methods and release-recapture designs for estimating the survival of very small fish: examples from the assessment of salmonid fry survival - Rev. Fish. Sci. 17: 391-401

St. Pierre R.A. 1999 - Restoration of Atlantic sturgeon in the northeastern USA with special emphasis on culture and restocking - J. Appl. Ichthyol. 15: 180-182

Szczepkowski M., Szczepkowska B., Piotrowska I. 2011 Impact of higher stocking density of juvenile Atlantic sturgeon, Acipenser oxyrinchus Mitchill, on fish growth, oxygen consumption, and ammonia excretion - Arch. Pol. Fish. 19: 59-67.

Wu J.M., Wei Q.W., Du H., Wang C.Y., Zhang H. 2014 - Initial evaluation of the release programme for Dabry's sturgeon (Acipenser dabryanus Duméril, 1868) in the upper Yangtze River - J. Appl. Ichthyol. 30: 1423-1427.

Zale A.V., Parrish D.L., Sutton T.M. 2012 - Fisheries techniques, 3rd edition - American Fisheries Society, Bethesda, Maryland.

Zakęś Z., Kapusta A., Hopko M., Szczepkowski M., Kowalska A. 2015 - Growth, survival and tag retention in juvenile pikeperch (Sander lucioperca) in laboratory conditions Aquac. Res. 46: 1276-1280. 